\title{
Changes in the rumen bacterial community in response to sunflower oil and fish oil supplements in the diet of dairy sheep
}

\author{
A. Belenguer, ${ }^{1}$ P. G. Toral, P. Frutos, and G. Hervás \\ Instituto de Ganadería de Montaña (CSIC-Universidad de León), Finca Marzanas s/n, 24346 Grulleros, León, Spain
}

\begin{abstract}
Rumen microbial biohydrogenation of dietary unsaturated fatty acids has a major effect on the process of developing healthier dairy products. This study aimed to investigate in vivo the effect of diet supplementation with sunflower (SO) and fish (FO) oils on the rumen bacterial community in dairy sheep. First, 32 lactating ewes, divided in 8 lots of 4 animals each (2 lots per treatment), were fed a high-concentrate total mixed ration supplemented with $0,2 \% \mathrm{SO}, 1 \% \mathrm{FO}$, or $2 \%$ SO plus $1 \%$ FO. After $21 \mathrm{~d}$, rumen fluid samples were taken from each lot for DNA extraction and fluorescence in situ hybridization (FISH) analysis. In a second experiment, 5 cannulated ewes were first fed the same TMR, with the exception of a higher forage level, and then changed to the same diet supplemented with $2 \%$ SO plus $1 \%$ FO. After 0,3 , and $10 \mathrm{~d}$, rumen content samples were taken for DNA extraction and FISH analysis (fluid). Total bacteria and the Butyrivibrio group were studied in microbial DNA by terminal RFLP analysis (T-RFLP), and real-time PCR was used to quantify Butyrivibrio bacteria that produce vaccenic acid or stearic acid. In rumen fluid samples, total bacteria and clostridial clusters IX and XIV were analyzed by FISH. Dietary supplementation with SO plus FO seemed to induce important changes in the total bacteria and Butyrivibrio populations, and a high interindividual variation was observed, and the speed of the effect of the lipid supplementation depended on the individual microbial composition. Analysis by T-RFLP and FISH showed increases in cluster IX bacteria with SO plus FO supplementation, presumably Quinella-like microorganisms. The abundances of vaccenic acid- and stearic acid-producing Butyrivibrio relative to total bacteria, estimated by real time PCR, were low (0.28 and $0.18 \%$, respectively, in rumen fluid, and 0.86 and $0.81 \%$ in rumen contents) and only that of SA-producing bacteria seemed to be reduced by diets containing FO, although differences were only signifi-
\end{abstract}

Received January 22, 2010.

Accepted March 15, 2010.

${ }^{1}$ Corresponding author: a.belenguer@eae.csic.es cant in lactating ewes. The T-RFLP analysis showed a variable effect of lipid supplementation on different bacteria of the family Lachnospiraceae, which includes the cultured bacteria known to be actively involved in rumen biohydrogenation. These results suggest that the latter bacteria do not play a dominant role in this process, and therefore other as-yet-uncultivated microorganisms might be more relevant.

Key words: ewe, lipid supplementation, molecular technique, rumen microbiota

\section{INTRODUCTION}

Dairy products are the major source of potentially health-promoting conjugated linoleic acid in the human diet (Palmquist et al., 2005). Among conjugated linoleic acid isomers, cis-9 trans-11 18:2 (rumenic acid) is the most abundant in ruminant-derived foods, and it can be formed in the rumen from dietary linoleic acid via microbial biohydrogenation (BH) of fatty acids (FA) (Jenkins et al., 2008). This process may accumulate a wide range of intermediates (Palmquist et al., 2005), including rumenic acid, which is mostly reduced to trans-11 18:1 (vaccenic acid, VA) and finally to 18:0 (stearic acid, SA). Identifying which bacterial species have a role in biohydrogenation should aid in the process of developing healthier dairy products.

The ruminal formation of VA is also desirable because this FA can be desaturated to rumenic acid in the mammary gland and in other tissues (Palmquist et al., 2005). Vegetable oils rich in linoleic acid, such as sunflower oil (SO), provide the substrate for rumen VA synthesis, and marine products rich in long-chain polyunsaturated fatty acids, such as fish oil (FO), are potent inhibitors of the reduction of VA to SA (Lee et al., 2008). Thus, a combination of both oils (SO and FO) has been described as a good nutritional strategy to improve the milk FA profile in cows and sheep (Shingfield et al., 2006; Toral et al., 2010). However, unsaturated FA can be toxic to certain microorganisms, although some rumen bacteria are able to detoxify them through BH (Maia et al., 2007).

Thus far, the main bacterial species identified as being involved in the $\mathrm{BH}$ process belong to the Butyr- 
ivibrio group, which includes the genera Butyrivibrio and Pseudobutyrivibrio (Paillard et al., 2007a) and phylogenetically related bacteria (Devillard et al., 2007). Within this group, the only cultured SA-producing bacteria, initially identified as Fusocillus spp. (Kemp et al., 1975), are closely related to Clostridium proteoclasticum isolated by Wallace et al. (2006) and lately proposed for reclassification as Butyrivibrio proteoclasticus (Moon et al., 2008). Recently, Boeckaert et al. (2008) suggested that other, as-yet-uncultivated bacteria that cluster closely to the Butyrivibrio and Pseudobutyrivibrio genera might be more important for SA production than B. proteoclasticus. Other less abundant rumen bacteria, such as strains of Megasphaera elsdenii, may also have a role in BH (Jenkins et al., 2008).

In vitro studies have provided fundamental insight into the effect of lipids on rumen bacteria and the identification of microorganisms involved in rumen $\mathrm{BH}$. The relevance of individual strains in in vivo ruminal lipid metabolism and the effect of dietary unsaturated FA on bacterial community structure, however, remain largely unknown (Boeckaert et al., 2008). Complete in vivo $\mathrm{BH}$ is believed to be a synergistic process involving a bacterial consortium, with each microorganism having a share in the conversion of unsaturated to relatively more saturated FA (Harfoot and Hazlewood, 1997). Despite several studies examining the microbiology of FA metabolism, there is a lack of in vivo studies in sheep, which might have different biohydrogenating bacteria based on the suggested interspecies differences in lipid metabolism (Shingfield et al., 2009). The current investigation aimed to study the effect of dietary supplementation with $\mathrm{SO}$ and FO on the composition of the rumen bacterial community in sheep using cultivation-independent techniques, with a particular focus on bacterial populations previously reported to play a role in $\mathrm{BH}$.

\section{MATERIALS AND METHODS}

\section{Animals, Diets, and Experimental Design}

Two experiments were carried out in accordance with Spanish Royal Decree 1201/2005 for the protection of animals used for experimental purposes.

Experiment 1. Thirty-two lactating ewes were fed a TMR based on (\% fresh matter basis) alfalfa hay (20\%) and a concentrate (25\% corn grain, $20 \%$ soybean meal, $15 \%$ barley grain, $9 \%$ beet pulp, $4.5 \%$ vitamin-mineral supplement, and $6.5 \%$ molasses to avoid selection of dietary components) for a 3 -wk adaptation period (before the beginning of the trial). Animals were distributed in 8 lots of 4 animals each and allocated at random to 4 experimental treatments (2 lots per treatment): TMR supplemented with 0 (control diet), $2 \%$ sunflower oil (SO diet), $1 \%$ fish oil (FO diet), and a combination of $2 \% \mathrm{SO}$ and 1\% FO (SOFO diet). Experimental diets were consumed for 3 wk before taking the samples.

Experiment 2. Detailed studies were also conducted on effects of lipid supplementation on the rumen bacteria over time. Five adult ewes, fitted with ruminal cannulas (40-mm internal diameter), were allocated in individual cages and fed the same TMR as described for experiment 1, with the exception that it contained $35 \%$ alfalfa hay (forage:concentrate ratio 35:65) for a $10-d$ adaptation period. Afterward, animals received the same TMR but supplemented with $2 \%$ SO plus $1 \%$ FO (SFO diet) for $11 \mathrm{~d}$.

In both experiments, fresh TMR was offered daily ad libitum at 0900 and $1900 \mathrm{~h}$, and clean water was always available.

\section{Rumen Sample Collection}

Experiment 1. After $21 \mathrm{~d}$ on treatments, animals were milked $(0830 \mathrm{~h})$ and given free access to the diets as on other days. After $2 \mathrm{~h}$, the feed was removed and $3 \mathrm{~h}$ later, samples of ruminal fluid were individually collected using a stomach tube. Samples were strained through 2 layers of muslin, mixed for each lot, and immediately frozen at $-80^{\circ} \mathrm{C}$ for DNA extraction. Aliquots of strained rumen fluid $(1 \mathrm{~mL})$ from each lot were diluted with filter-sterilized PBS $(0.14 \mathrm{M} \mathrm{NaCl}, 2.7 \mathrm{mM}$ $\mathrm{KCl}, 8.1 \mathrm{mM} \mathrm{Na}_{2} \mathrm{HPO}_{4}$, and $1.8 \mathrm{~m} M \mathrm{KH}_{2} \mathrm{PO}_{4}$, pH 7.4), and then fixed by being mixed $1: 3$ in $4 \%$ (wt/vol) paraformaldehyde at $4^{\circ} \mathrm{C}$ for $16 \mathrm{~h}$ and finally stored at $-20^{\circ} \mathrm{C}$ for fluorescence in situ hybridization (FISH) analysis.

Experiment 2. Samples of rumen contents were collected in the morning before feed administration via the cannula 3 times during the experiment, immediately before starting the administration of the SFO diet when the ewes were adapted to the consumption of the basal diet (d 0, control), after $3 \mathrm{~d}\left(\mathbf{S F O}_{3}\right.$; to study a possible prompt response), and after $10 \mathrm{~d}\left(\mathbf{S F O}_{10}\right)$ on the SFO diet. Even though the treatment may be confounded with the experimental period, this approach was used rather than a switchback design to allow adaptation of the sheep to the basal diet (i.e., the diet without supplementation) and to avoid a carryover effect of the oils on the rumen microbiota (Wasowska et al., 2006). Similar experimental designs have been previously used (e.g., Shingfield et al., 2003; Boeckaert et al., 2008). Total rumen contents were sampled and immediately frozen at $-80^{\circ} \mathrm{C}$ for DNA extraction. Another fraction of rumen contents was strained through 2 layers of muslin and the rumen fluid $(1 \mathrm{~mL})$ was diluted with PBS, 
Table 1. Primers used in this study for real-time PCR (qPCR) and terminal restriction fragment length polymorphism (T-RFLP), and probes employed for fluorescence in situ hybridization (FISH) analysis

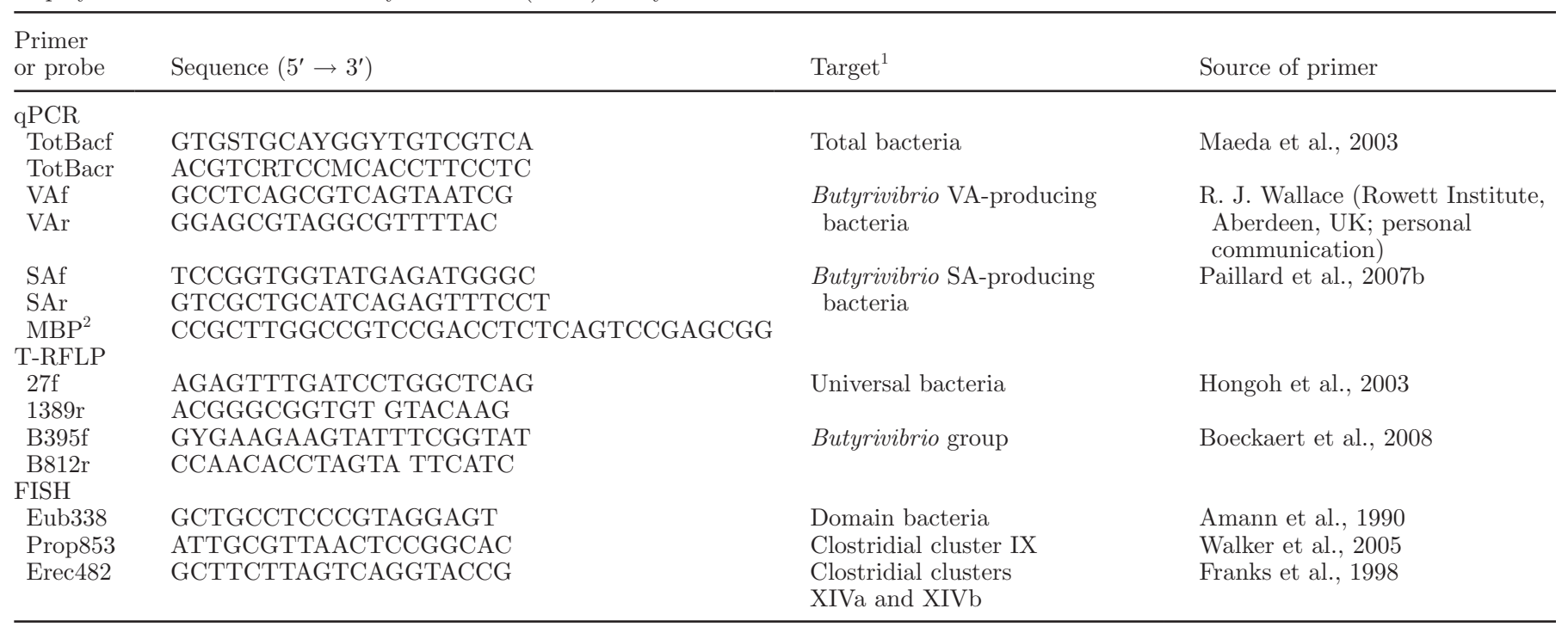

${ }^{1} \mathrm{VA}=$ vaccenic acid; $\mathrm{SA}=$ stearic acid.

${ }^{2}$ Molecular beacon probe.

processed as described in experiment 1, and finally stored at $-20^{\circ} \mathrm{C}$ for FISH analysis.

\section{DNA Extraction and Quantification}

Frozen rumen samples were freeze-dried and thoroughly mixed before DNA extraction, which was performed in duplicate by physical disruption using a bead beater (Mini-bead Beater, BioSpec Products, Bartlesville, $\mathrm{OK}$ ), following the protocol described by $\mathrm{Yu}$ and Morrison (2004), with the modification of a higher temperature $\left(95^{\circ} \mathrm{C}\right)$ to improve cell lysis. Duplicate DNA samples were combined and used as templates for quantitative real-time PCR (qPCR) amplification and terminal RFLP (T-RFLP) analysis. The DNA concentrations were measured by spectrophotometry (NanoDrop ND-1000 Spectrophotometer, Nanodrop Technologies, Wilmington, DE).

\section{qPCR Analysis}

Quantitative real-time PCR was carried out using the Applied Biosystems StepOne Plus Real Time PCR system (Applied Biosystems, Foster City, CA) to investigate the abundance of 2 bacterial groups potentially able to carry out rumen $\mathrm{BH}$ : Butyrivibrio VA-producing and Butyrivibrio SA-producing bacteria. The 16S rRNA gene-targeted primer sets used for qPCR analysis are presented in Table 1 . The PCR reactions were performed in duplicate or triplicate with SYBR Green Supermix (Takara Bio Inc., Otsu, Shiga, Japan) as described previously (Maeda et al., 2003), using a $20-\mu \mathrm{L}$ reaction mixture and $0.2 \mu \mathrm{L}$ of each primer $(10$ $\mu M$ ) for total bacteria and $0.4 \mu \mathrm{L}$ for Butyrivibrio VAproducing bacteria. For the detection of the Butyrivibrio SA-producing bacteria (B. proteoclasticus group) using qPCR, the molecular beacon approach with the primers and probe designed by Paillard et al. (2007b) was employed.

The primers used to detect Butyrivibrio VA-producing bacteria were tested for their specificity with Butyrivibrio fibrisolvens JW11 as positive control, and Mitsuokella multiacidus 46/5, B. proteoclasticum P18, Ruminococcus albus SY3, M. elsdenii J1, and Selenomonas ruminantium Z108 were used as negative controls. Genomic DNA was extracted from pure cultures of the bacterial strains, most of them obtained from R. J. Wallace and N. McKain (Rowett Institute of Health and Nutrition, Aberdeen, UK), except for strains J1 and SY3 that were gifts from C. J. Newbold (Institute of Biological, Environmental and Rural Sciences, Aberystwyth, UK).

Dilutions of purified genomic DNA from control strains (B. fibrisolvens JW11 as a Butyrivibrio VAproducer and $B$. proteoclasticus $\mathrm{P} 18$ as a representative of the Butyrivibrio SA-producing bacteria) were used to construct species-specific calibration curves and to check the PCR amplification efficiency for the relative quantification of specific DNA in rumen DNA preparations, which was performed following Pfaffl (2001). The qPCR efficiency ranged between 86 and $100 \%$ for the analysis of rumen samples for both biohydrogenating 
groups and universal bacteria. Negative controls without DNA template were run with every assay to assess the overall specificity.

\section{T-RFLP Analysis}

Two different T-RFLP analyses were performed, the first using a universal bacteria-specific primer pair set (Hongoh et al. 2003) and the second analysis using Butyrivibrio group-specific primers (Boeckaert et al. 2008; Table 1). Both forward primers were labeled with 6-carboxy-fluorescein (FAM) and procedures were as described previously (Castillo et al., 2007), using 2 restriction enzymes for the total bacteria analysis (HhaI and MspI) and only 1 for the Butyrivibrio group T-RFLP (HhaI). The fluorescently labeled terminal restriction fragments (T-RF) were analyzed by capillary electrophoresis on an automatic sequence analyzer (MegaBace 500, GE Healthcare Life Sciences, Buckinghamshire, UK). Determination of the sizes of T-RF was performed with the size standard ET 500-R (GE Healthcare Life Sciences), and data were analyzed using the GeneMarker Analysis software (SoftGenetics, State College, PA).

Sample data consisted of size (bp) and peak area for each T-RF analyzed as described by Castillo et al. (2007). Based on the binary data generated, the number of T-RF (richness) and the Shannon-Wiener and Shannon evenness indices (Hill et al., 2003) were determined.

To infer the potential bacterial composition in the samples, in silico restriction for the major rumen bacteria with the primers and the enzymes used were obtained from the Ribosomal Database Project II Web site (http://rdp.cme.msu.edu/index.jsp; Cole et al., 2009).

\section{FISH Analysis}

For FISH analysis, diluted cell suspensions were applied to gelatin-coated slides. Samples were prepared as described previously (Belenguer et al., 2007). Images were captured with an epifluorescence microscope equipped with a digital camera (Nikon Eclipse TE000-E, Nikon Instruments, Melville, NY) using the Metamorph imaging software version 7.1 (Universal Imaging, Downington, PA). Cells in 25 microscopic fields were counted for each sample. The samples were assessed with the probes Prop853 and Erec482 (Table 1). Total bacterial numbers were estimated using the universal probe Eub338 (Amann et al., 1990).

\section{Statistical Analysis}

All data were analyzed by one-way ANOVA, using the MIXED procedure of the SAS software package, version 9.1 (SAS Inst. Inc., Cary, NC). Some qPCR data did not meet the ANOVA requirement of normality and were $\log _{10}$-transformed for the analysis. The statistical models included the fixed effect of treatment (control, SO, FO, and $\mathrm{SOFO}$ in experiment 1, and control, $\mathrm{SFO}_{3}$ and $\mathrm{SFO}_{10}$ in experiment 2), and the lot (experiment 1) or animal (experiment 2) as a random effect that was nested within the treatment and used as the error term to contrast the effect of oil supplementation. Means were separated using the "pdiff" option of the "lsmeans" statement of the MIXED procedure. Significant differences were declared at $P<0.05$ and tendencies at $P<0.10$.

Data from T-RFLP were analyzed using hierarchical clustering, with the Ward's method based on Jaccard distances $(1-$ Jaccard coefficient). This statistic (Jaccard coefficient) measures similarity between samples and is defined as the ratio of the number of T-RF in common between 2 profiles to the total number of T-RF present in those profiles. This agglomerative hierarchical clustering was applied to obtain dendrograms from the data obtained by the 2 single-enzyme ( $H h a \mathrm{I}$ and $M s p \mathrm{I}$ ) digestions for the total bacteria and by the $H h a \mathrm{I}$ digestion for the Butyrivibrio group with the Community Analysis Package 4 software (Pisces Conservation Ltd., Lymington, UK).

\section{RESULTS}

\section{Bacterial Community Analysis by T-RFLP}

The T-RFLP analysis of $16 \mathrm{~S}$ rRNA genes using universal primers for bacteria indicated complex communities in all samples, with over 40 peaks after HhaI digestion and more than 60 peaks after $M s p I$ digestion. The diversity indices (richness, Shannon-Wiener, and Shannon evenness) were similar for all experimental treatments from HhaI and MspI digestions (Table 2), except in cannulated ewes after $10 \mathrm{~d}$ of SFO administration, when bacterial diversity estimated in data derived from HhaI digestion decreased, as reflected by the Shannon-Wiener $(P=0.04)$ and Shannon evenness indices $(P<0.01)$.

In lactating ewes (experiment 1), the samples derived from the SOFO-fed animals were grouped in a separate subcluster by the cluster analysis (Figure 1a), suggesting that the combination of the lipid sources together (SOFO) induced similar and important shifts in bacterial communities.

In cannulated ewes (experiment 2), the $\mathrm{SFO}_{10} \mathrm{~T}$ RFLP pattern showed, in general, greater differences compared with the control treatment (average percentage similarity $53 \%$ ) than with the $\mathrm{SFO}_{3}(>55 \%)$, although a variable response depending on the individual 
a)

\begin{tabular}{llllll}
\hline 0.605 & 0.552 & 0.491 & 0.444 & 0.322 & 0
\end{tabular}

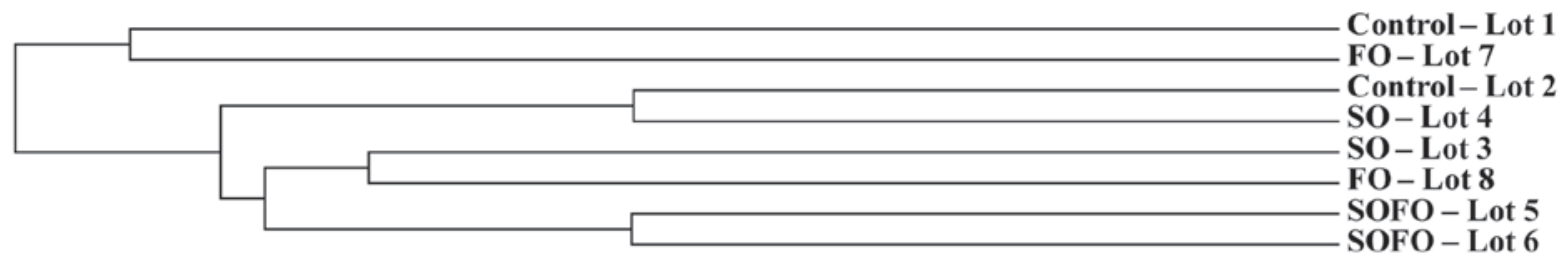

b)

\begin{tabular}{lllll}
\hline 0.749 & 0.562 & 0.374 & 0.187 & 0
\end{tabular}

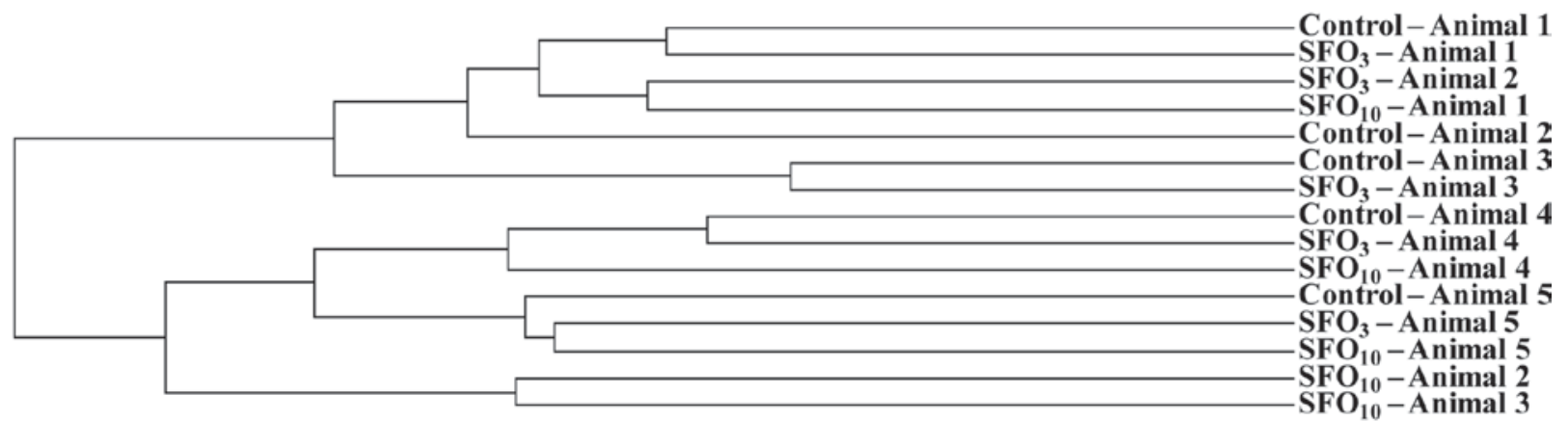

c)

\begin{tabular}{llllll}
\hline 0.835 & 0.730 & 0.616 & 0.528 & 0.463 & 0
\end{tabular}

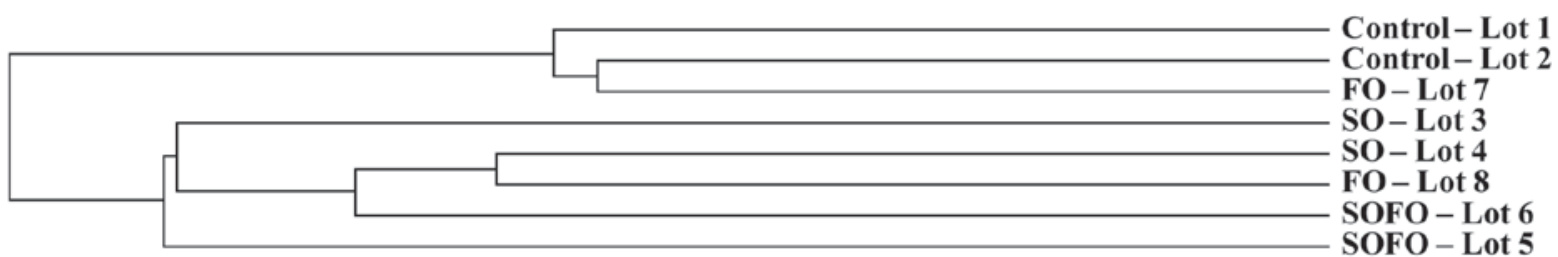

d)

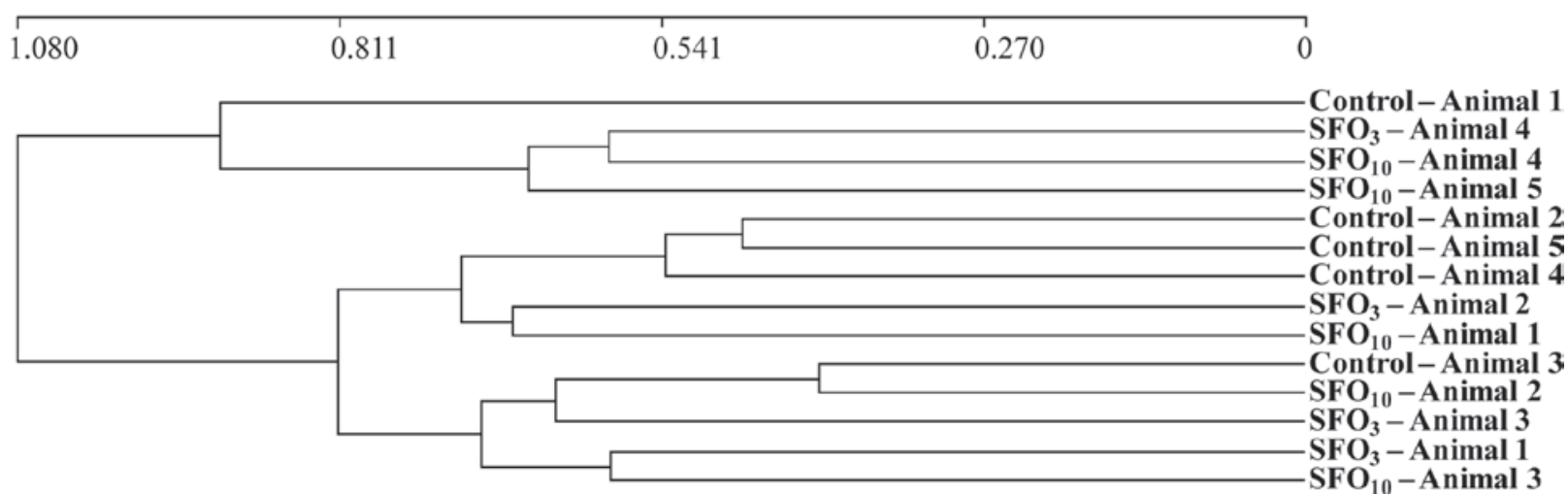

Figure 1. Terminal-RFLP-derived Ward's method with Jaccard distances dendrograms showing the effect on the total bacteria (a, b) and Butyrivibrio population (c, d) in DNA extracted from rumen fluid of lactating ewes receiving a diet with no lipid supplementation (control) or supplemented with $2 \%$ sunflower oil (SO), $1 \%$ fish oil (FO), or $2 \%$ SO plus $1 \%$ FO (SOFO) in experiment 1 (a, c), and from rumen contents of cannulated ewes collected after 0 (control), $3\left(\mathrm{SFO}_{3}\right)$ and $10\left(\mathrm{SFO}_{10}\right)$ d on a diet supplemented with $2 \% \mathrm{SO}$ plus $1 \%$ FO in experiment 2 (b, d). 
Table 2. Diversity indices (richness, R; Shannon-Wiener, H; and Shannon evenness, E) calculated from the total bacteria and the Butyrivibrio group-specific terminal ( $\mathrm{T}$ )-RFLP profiles obtained from rumen fluid of lactating ewes receiving different experimental diets in experiment 1 and from rumen contents of cannulated ewes collected at different times in experiment 2

\begin{tabular}{|c|c|c|c|c|c|c|c|c|c|}
\hline Item & \multicolumn{6}{|c|}{ Total bacteria } & \multicolumn{3}{|c|}{ Butyrivibrio } \\
\hline \multicolumn{10}{|c|}{ Experiment $1^{1}$} \\
\hline Control & 45.0 & 2.40 & 0.63 & 62.0 & 2.92 & 0.71 & 37.0 & 2.96 & 0.82 \\
\hline $\mathrm{SO}$ & 50.0 & 2.40 & 0.61 & 71.0 & 2.98 & 0.70 & 23.5 & 2.08 & 0.66 \\
\hline $\mathrm{SED}^{2}$ & 7.40 & 0.361 & 0.070 & 14.67 & 0.392 & 0.061 & 5.28 & 0.241 & 0.044 \\
\hline$P$-value ${ }^{3}$ & 0.87 & 0.97 & 0.95 & 0.92 & 0.99 & 0.98 & 0.21 & 0.09 & 0.08 \\
\hline \multicolumn{10}{|c|}{ Experiment $2^{4}$} \\
\hline Control & 59.2 & $3.07^{\mathrm{a}}$ & $0.75^{\mathrm{a}}$ & 82.4 & 3.61 & 0.82 & 21.4 & 1.83 & 0.61 \\
\hline $\mathrm{SFO}_{3}$ & 55.2 & $2.97^{\mathrm{ab}}$ & $0.74^{\mathrm{a}}$ & 75.8 & 3.53 & 0.82 & 24.7 & 2.08 & 0.65 \\
\hline $\mathrm{SFO}_{10}$ & 58.0 & $2.73^{\mathrm{b}}$ & $0.67^{\mathrm{b}}$ & 74.6 & 3.38 & 0.78 & 21.8 & 1.94 & 0.63 \\
\hline SED & 4.70 & 0.112 & 0.018 & 3.73 & 0.104 & 0.018 & 4.37 & 0.158 & 0.047 \\
\hline
\end{tabular}

${ }^{\mathrm{a}, \mathrm{b}}$ For each experiment, means within a column with different superscripts differ significantly $(P<0.05)$.

${ }^{1}$ Control $=$ with no lipid supplementation; $\mathrm{SO}=$ supplemented with $2 \%$ sunflower oil; FO $=1 \%$ fish oil; SOFO = $2 \% \mathrm{SO}$ plus $1 \% \mathrm{FO}$.

${ }^{2} \mathrm{SED}=$ standard error of the difference.

${ }^{3}$ Probability of significant effects of experimental diet.

${ }^{4}$ Collected after 0 (control), $3\left(\mathrm{SFO}_{3}\right)$, and $10\left(\mathrm{SFO}_{10}\right)$ d on a diet supplemented with $2 \%$ SO plus $1 \%$ FO.

rumen microbiota was observed. It is remarkable that samples from each animal are clustered together, except those collected after $10 \mathrm{~d}\left(\mathrm{SFO}_{10}\right)$ from animals 2 and 3 (Figure $1 \mathrm{~b}$ ).

The relative frequency out of the total peak area for several matching T-RF, which showed a similar effect with either HhaI or $M s p I$, was different among treatments. In silico restriction allows the assignment of potential bacterial species to these fragments (Table 3 ). One of these T-RF (66 bp with HhaI) may correspond to bacteria of the order Clostridiales and was reduced by the SOFO diet in lactating ewes. In experiment 2, 2 Clostridiales-compatible fragments (181 bp and 361 bp with HhaI), which might correspond to uncultured microorganisms of the family Lachnospiraceae (Table 3 ), showed a reduction with SFO consumption. Different T-RF (99 bp and 390 bp with HhaI), which may correspond to bacteria belonging to cluster IX of the Clostridium subphylum (Collins et al., 1994), increased their abundance when both $\mathrm{SO}$ and $\mathrm{FO}$ were combined in the diet of lactating ewes. Similar clostridial cluster IX-compatible fragments (390 bp with HhaI, and 275 bp with $M s p \mathrm{I}$ ) increased their relative frequency in cannulated sheep on the $\mathrm{SFO}_{10}$ treatment. Conversely, the relative frequency of a Prevotella-compatible T-RF (102 bp with HhaI) was strongly reduced by lipid supplementation in lactating ewes, although it was hardly detected in cannulated sheep.

Table 3. Range of frequencies over the total peak area (\%) of some fragments (terminal restriction fragments, T-RF) identified by terminalRFLP in rumen samples collected from ewes receiving diets supplemented with sunflower oil or fish oil or both, and their potential compatible bacteria $^{1}$

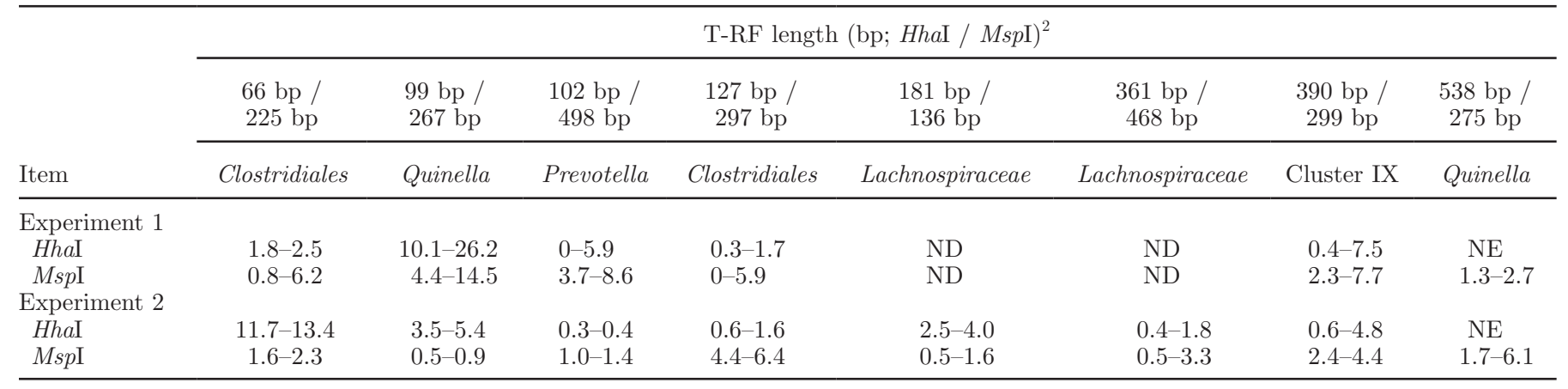

${ }^{1} \mathrm{ND}=$ not detected; $\mathrm{NE}=$ not estimated.

${ }^{2}$ Potentially compatible bacteria shown below each T-RF length pair. 
Table 4. Quantity of bacterial DNA of Butyrivibrio vaccenic acid (VA)- and stearic acid (SA)-producing bacteria, determined by real-time PCR, expressed as a $\log _{10}$ of the percentage (\%; nontransformed values in parentheses) of the total genomic bacterial DNA and of the specific DNA concentration ( $\mathrm{pg} / \mathrm{ng}$ total DNA; nontransformed values in parentheses), in total DNA extracted from rumen fluid of lactating ewes receiving different experimental diets in experiment 1 and from rumen contents of cannulated ewes collected at different times in experiment 2

\begin{tabular}{|c|c|c|c|c|}
\hline \multirow[b]{2}{*}{ Item } & \multicolumn{2}{|c|}{ VA-producing bacteria $\left(\log _{10}\right)$} & \multicolumn{2}{|c|}{ SA-producing bacteria $\left(\log _{10}\right)$} \\
\hline & $\%$ & $\mathrm{pg} / \mathrm{ng}$ of total DNA & $\%$ & $\mathrm{pg} / \mathrm{ng}$ of total DNA \\
\hline \multicolumn{5}{|c|}{ Experiment $1^{1}$} \\
\hline Control & $\begin{array}{c}-0.309 \\
(0.525)\end{array}$ & $\begin{array}{c}0.326 \\
(2.967)\end{array}$ & $\begin{array}{r}-0.937 \\
(0.120)\end{array}$ & $\begin{array}{c}0.073^{\mathrm{a}} \\
(1.186)\end{array}$ \\
\hline $\mathrm{SO}$ & $\begin{array}{c}-0.675 \\
(0.213)\end{array}$ & $\begin{array}{r}-0.377 \\
(0.452)\end{array}$ & $\begin{array}{c}-0.679 \\
(0.238)\end{array}$ & $\begin{array}{r}-0.017^{\mathrm{a}} \\
(0.962)\end{array}$ \\
\hline FO & $\begin{array}{c}-0.687 \\
(0.206)\end{array}$ & $\begin{array}{c}-0.597 \\
(0.254)\end{array}$ & $\begin{array}{c}-0.657 \\
(0.222)\end{array}$ & $\begin{array}{r}-0.277^{b} \\
(0.533)\end{array}$ \\
\hline SOFO & $\begin{array}{c}-0.772 \\
(0.176)\end{array}$ & $\begin{array}{c}-0.606 \\
(0.252)\end{array}$ & $\begin{array}{c}-0.921 \\
(0.122)\end{array}$ & $\begin{array}{r}-0.456^{\mathrm{c}} \\
(0.351)\end{array}$ \\
\hline $\mathrm{SED}^{2}$ & 0.1473 & 0.2980 & 0.1875 & 0.0544 \\
\hline$P$-value ${ }^{3}$ & 0.11 & 0.09 & 0.39 & $<0.01$ \\
\hline \multicolumn{5}{|c|}{ Experiment $2^{4}$} \\
\hline Control & $\begin{array}{c}-0.106 \\
(0.886)\end{array}$ & $\begin{array}{c}0.292 \\
(2.159)\end{array}$ & $\begin{array}{c}-0.108 \\
(0.836)\end{array}$ & $\begin{array}{c}0.626 \\
(4.502)\end{array}$ \\
\hline $\mathrm{SFO}_{3}$ & $\begin{array}{c}-0.061 \\
(0.922)\end{array}$ & $\begin{array}{c}0.237 \\
(1.839)\end{array}$ & $\begin{array}{c}-0.055 \\
(0.953)\end{array}$ & $\begin{array}{c}0.674 \\
(4.970)\end{array}$ \\
\hline $\mathrm{SFO}_{10}$ & $\begin{array}{c}-0.191 \\
(0.777)\end{array}$ & $\begin{array}{c}0.072 \\
(1.482)\end{array}$ & $\begin{array}{c}-0.236 \\
(0.639)\end{array}$ & $\begin{array}{c}0.361 \\
(2.903)\end{array}$ \\
\hline SED & 0.1144 & 0.1305 & 0.1305 & 0.1525 \\
\hline$P$-value & 0.54 & 0.27 & 0.40 & 0.15 \\
\hline
\end{tabular}

${ }^{a-c}$ For each experiment, means within a column with different superscripts differ significantly $(P<0.05)$.

${ }^{1} \mathrm{Control}=$ with no lipid supplementation; $\mathrm{SO}=$ supplemented with $2 \%$ sunflower oil; $\mathrm{FO}=1 \%$ fish oil; SOFO $=2 \% \mathrm{SO}$ plus $1 \% \mathrm{FO}$.

${ }^{2} \mathrm{SED}=$ standard error of the difference.

${ }^{3}$ Probability of significant effects of experimental diet.

${ }^{4}$ Collected after 0 (control), $3\left(\mathrm{SFO}_{3}\right)$, and $10\left(\mathrm{SFO}_{10}\right)$ d on a diet supplemented with $2 \% \mathrm{SO}$ plus $1 \% \mathrm{FO}$.

\section{Butyrivibrio Population Analysis by T-RFLP}

The T-RFLP analysis of $16 \mathrm{~S}$ rRNA genes for members of the Butyrivibrio group showed a less complex pattern than that of total bacteria. Diversity indices did not change with any of the dietary treatments (Table 2), except in lactating ewes, which tended to show lower Shannon-Wiener $(P=0.09)$ and Shannon evenness $(P$ $=0.08$ ) indices in samples derived from animals on the $\mathrm{SO}$ treatment than in those obtained from sheep receiving the control diet.

Hierarchical analysis on data from experiment 1 resulted in 2 major clusters, with most samples extracted from animals fed lipid-supplemented diets being located in the same cluster, except one from the FO treatment that grouped with the control diet (Figure 1c). The SOFO profiles were the least similar to the control group (percentage similarity $<30 \%$ ).

In experiment 2, the DNA extracted from the sample obtained from animal 5 on the $\mathrm{SFO}_{3}$ treatment failed to amplify with the Butyrivibrio group-specific primers and could not be analyzed. No clusters due to dietary treatment or to differences in the individual microbiota composition were observed (Figure 1d). Within each animal, percentage similarities between T-RFLP patterns after 0 (control) and $3\left(\mathrm{SFO}_{3}\right) \mathrm{d}$ on the $\mathrm{SFO}$ diet were already lower than $44 \%$.

In the samples derived from the SOFO-fed lactating ewes, 3 unique T-RF (182, 185, and $189 \mathrm{bp}$ ) were detected. Interestingly, the 176-bp T-RF disappeared in the samples derived from the SOFO group. Furthermore, the relative frequency of the 299-bp T-RF was stimulated by the dietary combination of the oils in both experiments.

\section{Microbial Population Analysis by $q P C R$}

Quantification of the $16 \mathrm{~S}$ rRNA gene copy number of the Butyrivibrio VA-producing bacteria showed no changes caused by the experimental treatments in their relative proportions of the total bacteria (Table 4), average values being 0.28 and $0.86 \%$ in the samples derived from lactating ewes (experiment 1 ) and from cannulated sheep (experiment 2), respectively. When expressed as DNA concentration ( $\mathrm{pg} / \mathrm{ng}$ of total DNA), however, the abundance of the Butyrivibrio VA-producing bacteria 
Table 5. Counts ( $\log _{10}$; nontransformed values in parentheses) of total bacteria per milliliter of rumen fluid (using the universal probe Eub338) and the bacterial groups clostridial cluster IX (probe Prop853), clostridial clusters XIVa and XIVb (probe Erec482), and a subgroup of the clostridial cluster IX (large oval bacteria) in lactating ewes receiving different experimental diets in experiment 1 and in cannulated ewes with rumen fluid collected at different times in experiment 2

\begin{tabular}{|c|c|c|c|c|}
\hline Item & Eub338 & Erec482 & Prop853 & Oval bacteria \\
\hline \multicolumn{5}{|c|}{ Experiment $1^{1}$} \\
\hline Control & $\begin{array}{l}9.41 \\
\left(2.60 \times 10^{9}\right)\end{array}$ & $\begin{array}{l}8.56 \\
\left(3.65 \times 10^{8}\right)\end{array}$ & $\begin{array}{l}8.24 \\
\left(1.77 \times 10^{8}\right)\end{array}$ & $\begin{array}{l}6.97 \\
\left(9.36 \times 10^{6}\right)\end{array}$ \\
\hline $\mathrm{SO}$ & $\begin{array}{l}9.45 \\
\left(2.80 \times 10^{9}\right)\end{array}$ & $\begin{array}{l}8.59 \\
\left(3.96 \times 10^{8}\right)\end{array}$ & $\begin{array}{l}8.33 \\
\left(3.50 \times 10^{8}\right)\end{array}$ & $\begin{array}{l}7.34 \\
\left(2.60 \times 10^{7}\right)\end{array}$ \\
\hline $\mathrm{FO}$ & $\begin{array}{l}9.47 \\
\left(2.95 \times 10^{9}\right)\end{array}$ & $\begin{array}{l}8.38 \\
\left(2.45 \times 10^{8}\right)\end{array}$ & $\left(4.54 \times 10^{8}\right)$ & $\begin{array}{l}7.69 \\
\left(5.27 \times 10^{7}\right)\end{array}$ \\
\hline SOFO & $\begin{array}{l}9.47 \\
\left(2.96 \times 10^{9}\right)\end{array}$ & $\begin{array}{l}8.47 \\
\left(2.93 \times 10^{8}\right)\end{array}$ & $\begin{array}{l}8.79 \\
\left(6.22 \times 10^{8}\right)\end{array}$ & $(5.71$ \\
\hline $\mathrm{SED}^{2}$ & 0.029 & 0.089 & 0.351 & 0.232 \\
\hline$P$-value ${ }^{3}$ & 0.32 & 0.21 & 0.46 & 0.09 \\
\hline \multicolumn{5}{|c|}{ Experiment $2^{4}$} \\
\hline Control & $\begin{array}{l}9.89^{\mathrm{a}} \\
\left(9.01 \times 10^{9}\right)\end{array}$ & $\begin{array}{l}8.58 \\
\left(4.06 \times 10^{8}\right)\end{array}$ & $\begin{array}{l}8.78 \\
\left(6.41 \times 10^{8}\right)\end{array}$ & $\begin{array}{l}7.44^{\mathrm{b}} \\
\left(2.75 \times 10^{7}\right)\end{array}$ \\
\hline $\mathrm{SFO}_{3}$ & $\begin{array}{l}9.56^{\mathrm{b}} \\
\left(4.17 \times 10^{9}\right)\end{array}$ & $\begin{array}{l}8.68 \\
\left(5.11 \times 10^{8}\right)\end{array}$ & $\left(7.11 \times 10^{8}\right)$ & $\left(1.91 \times 10^{7}\right)$ \\
\hline $\mathrm{SFO}_{10}$ & $\begin{array}{l}9.74^{\mathrm{ab}} \\
\left(5.64 \times 10^{9}\right)\end{array}$ & $\begin{array}{l}8.70 \\
\left(5.54 \times 10^{8}\right)\end{array}$ & $\begin{array}{l}8.91 \\
\left(9.12 \times 10^{8}\right)\end{array}$ & $\begin{array}{l}7.87^{\mathrm{a}} \\
\left(7.41 \times 10^{7}\right)\end{array}$ \\
\hline SED & 0.084 & 0.121 & 0.107 & 0.158 \\
\hline$P$-value & 0.01 & 0.61 & 0.52 & 0.01 \\
\hline
\end{tabular}

${ }^{a, b}$ For each experiment, means within a column with different superscripts differ significantly $(P<0.05)$.

${ }^{1}$ Control $=$ with no lipid supplementation; $\mathrm{SO}=$ supplemented with $2 \%$ sunflower oil; FO $=1 \%$ fish oil; SOFO

$=2 \% \mathrm{SO}$ plus $1 \% \mathrm{FO}$.

${ }^{2} \mathrm{SED}=$ standard error of the difference.

${ }^{3}$ Probability of significant effects of experimental diet.

${ }^{4}$ Collected after 0 (control), $3\left(\mathrm{SFO}_{3}\right)$, and $10\left(\mathrm{SFO}_{10}\right)$ d on a diet supplemented with $2 \%$ SO plus $1 \%$ FO.

tended to be lower $(P=0.09)$ in lactating ewes fed diets supplemented with lipid sources, especially with FO (FO and SOFO diets), although that effect was not observed in experiment 2 .

The relative abundances of the Butyrivibrio SA-producing bacteria (B. proteoclasticus group) $16 \mathrm{~S}$ rRNA gene copy number averaged $0.18 \%$ of total bacteria in experiment 1 and $0.81 \%$ in experiment 2 , and it was not affected by dietary treatment (Table 4). However, in terms of $16 \mathrm{~S}$ rRNA gene concentration ( $\mathrm{pg} / \mathrm{ng}$ of total DNA), the $B$. proteoclasticus group was reduced when FO was included in the diet, the abundance being lower $(P<0.01)$ in the samples derived from the FO- or SOFO-fed lactating ewes, whereas in cannulated sheep on the $\mathrm{SFO}_{10}$ treatment the concentration was only numerically smaller $(P=0.15)$ but not different from the control or $\mathrm{SFO}_{3}$ treatments.

\section{Enumeration of Bacteria in Rumen Samples by FISH Analysis}

Total numbers of bacteria, estimated with the Eub338 probe, were similar in all groups in experiment 1 (Table 5 ), with an average value of $9.45 \log _{10}$ cells $/ \mathrm{mL}$. However, in experiment 2, total numbers of bacteria were reduced $(P=0.01)$ after $3 \mathrm{~d}$ of $\mathrm{SFO}$ consumption, although they recovered on d $11\left(\mathrm{SFO}_{10}\right)$ and showed numbers similar to those on d 0 (control).

Probes targeted to clostridial clusters IX (Prop853) and XIVa and XIVb (Erec482) accounted for 14.4 to $40.0 \%$ of the bacteria present in the rumen fluid of lactating ewes, the proportion of the bacteria detected by the Erec 482 probe being greater than the proportion of the cluster IX representatives only with the control and SO diets. In experiment 2, high interindividual variability was observed and these probes accounted for 8.2 to $56.5 \%$ of the total bacteria. Unlike in experiment 1 , in experiment 2 , the proportion of cluster IX representatives was always greater than the bacteria detected by the Erec482 probe.

Bacteria belonging to the clostridial clusters XIVa and XIVb, detected with the Erec482 probe, showed average numbers of 8.50 and $8.65 \log _{10}$ cells $/ \mathrm{mL}$ in experiments 1 and 2 , respectively, with no variations caused by the experimental treatments. The numbers of bacteria belonging to the clostridial cluster IX, detected with the Prop853 probe, were not affected in experiment 1 or in experiment 2. Interestingly, within the latter group, large oval bacteria were observed and counted. The numbers of these oval microorgan- 
isms tended to be higher $(P=0.09)$ in lactating ewes fed the FO and SOFO diets and showed values higher than $7 \log _{10}$ cells $/ \mathrm{mL}$ in all groups receiving a lipidsupplemented diet and proportions up to $2.5 \%$ of total bacteria. In experiment 2 , their numbers were greater after $10 \mathrm{~d}$ of SFO supplementation $(P=0.01)$.

\section{DISCUSSION}

There is great interest in the study of ruminal microorganisms involved in lipid metabolism because of their effect on the quality of ruminant-derived products (Palmquist et al., 2005). Several studies have investigated the effect of lipid supplementation on the rumen microbiota in cattle, using molecular techniques (Boeckaert et al., 2007, 2008; Kim et al., 2008). However, interspecies differences between ruminants in lipid metabolism have been suggested (Shingfield et al., 2009) and no similar in vivo studies have been reported in sheep. This study showed that lipid supplementation with a combination of SO plus FO promoted changes in rumen microbial communities in vivo in sheep, including variations within the Butyrivibrio population and increases in the abundance of a bacterial subgroup of the clostridial cluster IX.

A concomitant study showed that the milk FA profile responded within a week to $\mathrm{SO}$ and FO diet supplementation in lactating ewes (Toral et al., 2010). The combination of both lipids together induced the greatest modifications in the milk FA profile (Toral et al., 2010) with no impairment of rumen fermentation (Toral et al., 2009a,b). Therefore, a diet supplemented with both $\mathrm{SO}$ and FO was offered to animals for a shorter period in the second experiment.

It is noteworthy that some experimental and sampling differences existed between experiments 1 and 2, which might explain, in part, the differences detected in microbial profiles. The forage:concentrate ratio in the diet was higher in the second experiment (20:80 vs. 35:65 in experiments 1 and 2, respectively), which may have a relevant effect on the rumen microbiota and consequently on the $\mathrm{BH}$ process (Fuentes et al., 2009). The sampling procedure (stomach tube vs. direct collection through the cannula) and sampling time (3 h postfeeding vs. prefeeding) were also different. The rumen samples collected with a stomach tube relied solely on the fluid fraction (Egan, 2005), even though differences between liquid- and solid-associated bacteria, including those involved in the ruminal biohydrogenation process, have been reported (Tajima et al., 1999; Boeckaert et al., 2009).

In the samples collected $3 \mathrm{~h}$ after the morning feeding (lactating ewes), there might be a dilution of rumen microbes with feed, water, and saliva (Mould et al., 2005).
Nonetheless, the time of sample collection appeared to have little effect on the assessment of bacterial diversity in the rumen ( $\mathrm{Li}$ et al., 2009), with the microbial taxonomy being affected to a greater extent by host animal than by sampling time. Although in experiment 1 different animals were used for each diet, the superior microbial growth rates expected at $3 \mathrm{~h}$ postfeeding may help to detect treatment effects rather than individual differences (Van Glyswyk et al., 1992).

The extent of the effect of dietary lipid supplementation on rumen bacterial communities seemed to depend on the level of oil supplementation, in agreement with a previous report in which the effect of FO was concentration-dependent (Kim et al., 2008). In addition, the speed of the response to lipid supplementation appeared to rely on individual bacterial composition. In fact, after $3 \mathrm{~d}$ of SFO supplementation, differences in bacterial composition among animals remained even larger than the treatment effect.

In silico restriction was used to deduce potential ecological changes by lipid supplementation, using Ribosomal Database Project II (Cole et al., 2009). Nevertheless, it should be noted that diverse phylogenetic groups can share similar or identically sized T-RF and, then, caution should be taken in the interpretation of results. However, the utilization of more than one restriction enzyme in different single digestions ( $\mathrm{HhaI}$ and $M s p I$ ) enhances the accuracy in the identification from database matches (Kitts, 2001).

An increase in the relative abundance of clostridial cluster IX-compatible fragments was found in both trials with SO plus FO supplementation. Some of these T-RF may match rumen bacteria related to Quinella ovalis (Deng et al., 2007), which is a large oval-shaped bacterium that belongs to the Selenomonas-Megasphaera-Sporomusa group (clostridial cluster IX) (Krumholz et al., 1993) and has been found in the rumen of sheep (Vicini et al., 1987) and steers (Tolosa, 2006) fed diets with molasses, as in the present experiments. Furthermore, FISH results showed increases in the numbers of large oval bacteria of clostridial cluster IX in the samples from animals fed lipid-supplemented diets, especially with both oils together, which seems to reinforce the hypothesis that the favored microorganisms are presumably Quinella-like bacteria. Quinella ovalis is known to have a metabolism similar to that of $S$. ruminantium (Orpin, 1972; Krumholz et al., 1993). Regarding their function in relation to $\mathrm{BH}$, further research is necessary to investigate if these bacteria can metabolize unsaturated FA or are simply not sensitive to their toxic effect.

So far, all bacteria that have been shown to be actively involved in rumen BH belong to the Butyrivibrio group (Devillard et al., 2007; Paillard et al., 2007a; Jenkins 
et al., 2008). An effect of lipid supplementation on the Butyrivibrio population has been previously observed, using FO (Kim et al., 2008) and marine algae rich in docosahexaenoic acid (Boeckaert et al., 2008), although the lower levels of supplementation did not seem to greatly affect this bacterial group, as previously observed (Kim et al., 2008). The relative abundances of the Butyrivibrio VA- and SA-producing bacteria were much lower than those reported in cattle (Paillard et al., 2007b), which suggests interspecies differences among ruminants. These bacteria might be more abundant in the solid-associated bacterial fraction, particularly $B$. proteoclasticus (Boeckaert et al., 2009), which might explain the lower relative abundances of both bacterial groups in lactating ewes (whose rumen samples were obtained by stomach tube) compared with the cannulated sheep.

Within the Butyrivibrio group, strains of the family Lachnospiraceae that have been recently identified in the rumen and are potentially able to biohydrogenate FA (Boeckaert et al., 2009) would match a fragment detected by T-RFLP that increased its relative frequency with the combination of $\mathrm{SO}$ and $\mathrm{FO}$ in both trials. However, lipid supplementation did not significantly affect the abundance of the Butyrivibrio VA-producing bacteria. Conversely, the concentration of B. proteoclasticus seemed to be reduced with the dietary inclusion of FO, although this effect was not significant in experiment 2 when the rumen contents were analyzed. In steers, a lack of a significant effect of FO on this bacterium has also been observed (Kim et al., 2008). The reported inhibitory effect of docosahexaenoic acid, present in FO, on SA-producing bacteria belonging to the B. proteoclasticus group (Maia et al., 2007) was not significant in cannulated sheep, although in a concomitant study, VA accumulated in the rumen with SFO supplementation (Toral et al., 2009b). These results, therefore, would suggest that the $B$. proteoclasticus group may not play a dominant role in the conversion of VA to SA and that other bacteria could be involved. Alternatively, the metabolic activity of the B. proteoclasticus group may not be proportional to $16 \mathrm{~S}$ rRNA gene concentration, as previously indicated (Kim et al., 2008; Fuentes et al., 2009).

In conclusion, supplementation of ewe diets with $2 \%$ $\mathrm{SO}$ and $1 \% \mathrm{FO}$ promoted important qualitative changes in the total bacteria and Butyrivibrio populations. The results from experiment 2 suggest that the speed of this effect relies on the individual microbial composition, although after $10 \mathrm{~d}$ of supplementation, bacterial profiles in all animals appeared to be altered, despite high interindividual variation. The changes caused by administration of SO plus FO might be due in part to variations in microorganisms of the family Lachno- spiraceae and to an increase in the abundance of members of the clostridial cluster IX, presumably Quinellalike bacteria. Within the Butyrivibrio population, a few uncultured strains of the family Lachnospiraceae were stimulated. Although great attention has been paid to some identified strains potentially involved in rumen BH (mostly within the Butyrivibrio group), the present results suggest that those reported bacteria do not play a dominant role in this process, whereas as-yet-uncultured bacteria of other groups might be stimulated by lipid supplementation and be more relevant. Further research is necessary to evaluate the potential role of all these bacteria in the rumen FA metabolism.

\section{ACKNOWLEDGMENTS}

A. Belenguer and P. G. Toral gratefully acknowledge receipt of a research contract and a predoctoral grant, respectively, from the Spanish National Research Council (CSIC, I3P Programme). This work was supported by the Spanish Ministry of Science and Innovation (Project AGL2008-04805-C02-02), the Council of Castile and Leon (Projects CSI01B08), and the Spanish National Research Council (Project 200940I034). The authors thank R. John Wallace and Nest McKain from the Rowett Institute of Nutrition and Health (Aberdeen, UK), and C. Jamie Newbold from the Institute of Biological, Environmental and Rural Sciences (Aberystwyth, UK) for kindly providing the bacterial strains. The authors gratefully acknowledge Sylvia H. Duncan from the Rowett Institute of Nutrition and Health (Aberdeen, UK) for helpful criticism of the manuscript.

\section{REFERENCES}

Amann, R. I., B. J. Binder, R. J. Olson, S. W. Chisholm, R. Devereux, and D. A. Stahl. 1990. Combination of $16 \mathrm{~S}$ rRNA-targeted oligonucleotide probes with flow cytometry for analyzing mixed microbial populations. Appl. Environ. Microbiol. 56:1919-1925.

Belenguer, A., S. H. Duncan, G. Holtrop, S. E. Anderson, G. E. Lobley, and H. J. Flint. 2007. Impact of $\mathrm{pH}$ on lactate formation and utilization by human fecal microbial communities. Appl. Environ. Microbiol. 73:6526-6533.

Boeckaert, C., V. Fievez, D. Van Hecke, W. Verstraete, and N. Boon. 2007. Changes in rumen biohydrogenation intermediates and ciliate protozoa diversity after algae supplementation to dairy cattle. Eur. J. Lipid Sci. Technol. 109:767-777.

Boeckaert, C., D. P. Morgavi, J. P. Jouany, L. Maignien, N. Boon, and V. Fievez. 2009. Role of the protozoan Isotricha prostoma, liquid-, and solid-associated bacteria in rumen biohydrogenation of linoleic acid. Animal 3:961-971.

Boeckaert, C., B. Vlaeminck, V. Fievez, L. Maignien, J. Dijkstra, and N. Boon. 2008. Accumulation of trans C18:1 fatty acids in the rumen after dietary algal supplementation is associated with changes in the Butyrivibrio community. Appl. Environ. Microbiol. 74:6923-6930

Castillo, M., S. M. Martin-Orue, M. Nofrarias, E. G. Manzanilla, and J. Gasa. 2007. Changes in caecal microbiota and mucosal morphology of weaned pigs. Vet. Microbiol. 124:239-247. 
Cole, J. R., Q. Wang, E. Cardenas, J. Fish, B. Chai, R. J. Farris, A. S. Kulam-Syed-Mohideen, D. M. McGarrell, T. Marsh, G. M. Garrity, and J. M. Tiedje. 2009. The Ribosomal Database Project: Improved alignments and new tools for rRNA analysis. Nucleic Acids Res. 37:D141-D145.

Collins, M. D., P. A. Lawson, A. Willems, J. J. Cordoba, J. FernandezGarayzabal, P. Garcia, J. Cai, H. Hippe, and J. A. E. Farrow. 1994. The phylogeny of the genus Clostridium: proposal of five new genera and eleven new species combination. Int. J. Syst. Bacteriol. 44:812-826.

Deng, W. D., M. Wanapat, S. C. Ma, J. Chen, D. M. Xi, T. B. He, Z. F. Yang, and H. M. Mao. 2007. Phylogenetic analysis of $16 \mathrm{~S}$ rDNA sequences manifest rumen bacterial diversity in gayals (Bos frontalis) fed fresh bamboo leaves and twigs (Sinarumdinaria). Asian-australas. J. Anim. Sci. 20:1057-1066.

Devillard, E., F. M. McIntosh, S. H. Duncan, and R. J. Wallace. 2007. Metabolism of linoleic acid by human gut bacteria: Different routes for biosynthesis of conjugated linoleic acid. J. Bacteriol. 189:2566-2570.

Egan, A. R. 2005. Experimental designs for rumen microbiology. Pages 3-22 in Methods in Gut Microbial Ecology for Ruminants. H. P. S. Makkar and C. S. McSweeney, ed. Springer, New York, NY.

Franks, A. H., H. J. Harmsen, G. C. Raangs, G. J. Jansen, F. Schut, and G. W. Welling. 1998. Variations of bacterial populations in human feces measured by fluorescent in situ hybridization with group-specific 16S rRNA-targeted oligonucleotide probes. Appl. Environ. Microbiol. 64:3336-3345.

Fuentes, M. C., S. Calsamiglia, P. W. Cardozo, and B. Vlaeminck. 2009. Effect of $\mathrm{pH}$ and level of concentrate in the diet on the production of biohydrogenation intermediates in a dual-flow continuous culture. J. Dairy Sci. 92:4456-4466.

Harfoot, C. G., and G. P. Hazlewood. 1997. Lipid metabolism in the rumen. Pages 382-426 in The Rumen Microbial Ecosystem. P. N. Hobson and C. S. Stewart, ed. Chapman \& Hall, London, UK.

Hill, T. C. J., K. A. Walsh, J. A. Harris, and B. F. Moffett. 2003. Using ecological diversity measures with bacterial communities. FEMS Microbiol. Ecol. 43:1-11.

Hongoh, Y., H. Yuzawa, M. Ohkuma, and T. Kudo. 2003. Evaluation of primers and PCR conditions for the analysis of $16 \mathrm{~S}$ rRNA genes from a natural environment. FEMS Microbiol. Lett. 221:299 304.

Jenkins, T. C., R. J. Wallace, P. J. Moate, and E. E. Mosley. 2008. Board-invited review: Recent advances in biohydrogenation of unsaturated fatty acids within the rumen microbial ecosystem. J. Anim. Sci. 86:397-412.

Kemp, P., R. W. White, and D. J. Lander. 1975. The hydrogenation of unsaturated fatty acids by five bacterial isolates from the sheep rumen, including a new species. J. Gen. Microbiol. 90:100-114.

Kim, E. J., S. A. Huws, M. R. Lee, J. D. Wood, S. M. Muetzel, R. J. Wallace, and N. D. Scollan. 2008. Fish oil increases the duodenal flow of long chain polyunsaturated fatty acids and trans-11 18:1 and decreases 18:0 in steers via changes in the rumen bacterial community. J. Nutr. 138:889-896.

Kitts, C. L. 2001. Terminal restriction fragment patterns: A tool for comparing microbial communities and assessing community dynamics. Curr. Issues Intest. Microbiol. 2:17-25.

Krumholz, L. R., M. P. Bryant, W. J. Brulla, J. L. Vicini, J. H. Clark, and D. A. Stahl. 1993. Proposal of Quinella ovalis gen. nov., sp. nov., based on phylogenetic analysis. Int. J. Syst. Bacteriol. 43:293-296.

Lee, M. R. F., K. J. Shingfield, J. K. S. Tweed, V. Toivonen, S. A. Huws, and N. D. Scollan. 2008. Effect of fish oil on ruminal biohydrogenation of C18 unsaturated fatty acids in steers fed grass or red clover silages. Animal 2:1859-1869.

Li, M., G. B. Penner, E. Hernandez-Sanabria, M. Oba, and L. L. Guan. 2009. Effects of sampling location and time, and host animal on assesment of bacterial diversity and fermentation parameters in the bovine rumen. J. Appl. Microbiol. doi:10.1111/j.13652672.2009.04376.x.

Maeda, H., C. Fujimoto, Y. Haruki, T. Maeda, S. Kokeguchi, M. Petelin, H. Arai, I. Tanimoto, F. Nishimura, and S. Takashiba.
2003. Quantitative real-time PCR using TaqMan and SYBR Green for Actinobacillus actinomicetescomitans, Porphyromonas gingivalis, Prevotella intermedia, tetQ gene and total bacteria. FEMS Immunol. Med. Microbiol. 39:81-86.

Maia, M. R., L. C. Chaudhary, L. Figueres, and R. J. Wallace. 2007. Metabolism of polyunsaturated fatty acids and their toxicity to the microflora of the rumen. Antonie van Leeuwenhoek 91:303-314.

Moon, C. D., D. M. Pacheco, W. J. Kelly, S. C. Leahy, D. Li, J. Kopecny, and G. T. Attwood. 2008. Reclassification of Clostridium proteoclasticum as Butyrivibrio proteoclasticus comb. nov., a butyrate-producing ruminal bacterium. Int. J. Syst. Evol. Microbiol. 58:2041-2045.

Mould, F. L., K. E. Kliem, R. Morgan, and R. M. Mauricio. 2005. In vitro microbial inoculum: A review of its function and properties. Anim. Feed Sci. Technol. 123:31-50.

Orpin, C. G. 1972. The culture in vitro of the rumen bacterium Quin's Oval. J. Gen. Microbiol. 73:523-530.

Paillard, D., N. McKain, L. C. Chaudhary, N. D. Walker, F. Pizette, I. Koppova, N. R. McEwan, J. Kopecny, P. E. Vercoe, P. Louis, and R. J. Wallace. 2007a. Relation between phylogenetic position, lipid metabolism and butyrate production by different Butyrivibrio-like bacteria from the rumen. Antonie van Leeuwenhoek 91:417-422.

Paillard, D., N. McKain, M. T. Rincon, K. J. Shingfield, D. I. Givens, and R. J. Wallace. 2007b. Quantification of ruminal Clostridium proteoclasticum by real-time PCR using a molecular beacon approach. J. Appl. Microbiol. 103:1251-1261.

Palmquist, D. L., A. L. Lock, K. J. Shingfield, and D. E. Bauman. 2005. Biosynthesis of conjugated linoleic acid in ruminants and humans. Adv. Food Nutr. Res. 50:179-217.

Pfaffl, M. W. 2001. A new mathematical model for relative quantification in real-time RT-PCR. Nucleic Acids Res. 29:2002-2007.

Shingfield, K. J., S. Ahvenjarvi, V. Toivonen, A. Arola, K. V. V. Nurmela, P. Huhtanen, and J. M. Griinari. 2003. Effect of dietary fish oil on biohydrogenation of fatty acids and milk fatty acid content in cows. Anim. Sci. 77:165-179.

Shingfield, K. J., L. Bernard, C. Leroux, and Y. Chilliard. 2009. Trans fatty acids and mammary lipogenesis in ruminants. Page 56 in XIth International Symposium on Ruminant Physiology. Ruminant Physiology. Digestion, Metabolism, and Effects of Nutrition on Reproduction and Welfare. Y. Chilliard, F. Glasser, Y. Faulconnier, F. Bocquier, I. Veissier, and M. Doreau, ed. Wageningen Academic Publishers, Wageningen, the Netherlands.

Shingfield, K. J., C. K. Reynolds, G. Hervás, J. M. Griinari, A. S. Grandison, and D. E. Beever. 2006. Examination of the persistency of milk fatty acid composition responses to fish oil and sunflower oil in the diet of dairy cows. J. Dairy Sci. 89:714-732.

Tajima, K., R. I. Aminov, T. Nagamine, K. Ogama, M. Nakamura, H. Matsui, and Y. Benno. 1999. Rumen bacterial diversity as determined by sequence analysis of $16 \mathrm{~S}$ rDNA libraries. FEMS Microbiol. Ecol. 29:159-169.

Tolosa, M. X. 2006. Molecular ecology of rumen bacterial populations in steers fed molasses diets. MS Thesis. School of Animal Studies, The University of Queensland, Brisbane, Australia.

Toral, P. G., A. Belenguer, P. Frutos, and G. Hervás. 2009a. Effect of the supplementation of a high-concentrate diet with sunflower and fish oils on ruminal fermentation in sheep. Small Rumin. Res. $81: 119-125$.

Toral, P. G., P. Frutos, G. Hervás, P. Gómez-Cortés, M. Juárez, and M. A. de la Fuente. 2010. Changes in milk fatty acid profile and animal performance in response to fish oil supplementation, alone or in combination with sunflower oil, in dairy ewes. J. Dairy Sci. 93:1604-1615.

Toral, P. G., G. Hervás, K. Shingfield, V. Toivonen, A. Belenguer, and P. Frutos. 2009b. Ruminal fatty acid profile and fermentation characteristics in ewes fed sunflower and fish oils. Pages 374-375 in XIth International Symposium on Ruminant Physiology. Ruminant Physiology. Digestion, Metabolism, and Effects of Nutrition on Reproduction and Welfare. Y. Chilliard, F. Glasser, Y. Faulconnier, F. Bocquier, I. Veissier, and M. Doreau, ed. Wageningen Academic Publishers, Wageningen, the Netherlands. 
Van Glyswyk, N. O., K. Wejdemar, and K. Kulander. 1992. Comparative growth rates of various rumen bacteria in clarified rumen fluid from cows and sheep fed different diets. Appl. Environ. Microbiol. 58:99-105.

Vicini, J. L., W. J. Brulla, C. L. Davis, and M. P. Bryant. 1987. Quin oval and other microbiota in the rumens of molasses-fed sheep. Appl. Environ. Microbiol. 53:1273-1276.

Walker, A. W., S. H. Duncan, E. C. McWilliam Leitch, M. W. Child, and H. J. Flint. 2005. pH and peptide supply can radically alter bacterial populations and short-chain fatty acid ratios within microbial communities from the human colon. Appl. Environ. Microbiol. 71:3692-3700.
Wallace, R. J., L. C. Chaudhary, N. McKain, N. R. McEwan, A. Richardson, P. Vercoe, N. Walker, and D. Paillard. 2006. Clostridium proteoclasticum: A ruminal bacterium that forms stearic acid from linoleic acid. FEMS Microbiol. Lett. 265:195-201.

Wasowska, I., M. R. Maia, K. M. Niedzwiedzka, M. Czauderna, J. M. Ribeiro, E. Devillard, K. J. Shingfield, and R. J. Wallace. 2006. Influence of fish oil on ruminal biohydrogenation of $\mathrm{C} 18$ unsaturated fatty acids. Br. J. Nutr. 95:1199-1211.

Yu, Z., and M. Morrison. 2004. Improved extraction of PCR-quality community DNA from digesta and fecal samples. Biotechniques $36: 808-812$. 